CLINICAL STUDY

\title{
Sequential hormonal changes in 21 patients with recurrent Cushing's disease after successful pituitary surgery
}

Roula Bou Khalil ${ }^{1}$, Camille Baudry ${ }^{1,2,3,4}$, Laurence Guignat ${ }^{1}$, Carmen Carrasco ${ }^{1,2}$, Jean Guibourdenche ${ }^{3,5}$, Stéphane Gaillard $^{6}$, Xavier Bertagna ${ }^{1,2,3}$ and Jérôme Bertherat ${ }^{1,2,3}$

${ }^{1}$ Centre de Référence des Maladies Rares de la Surrénale, Service des Maladies Endocriniennes et Métaboliques, Hôpital Cochin, 27, rue du Faubourg St-Jacques, 75014 Paris, France, ${ }^{2}$ INSERM U1016, CNRS UMR8104, Institut Cochin, 75014 Paris, France, ${ }^{3}$ Université Paris Descartes, Sorbonne Cité, 75005 Paris, France, ${ }^{4}$ Unité de Biostatistiques et Epidémiologie EA 4360 APEMAC Université Paris Descartes, Hôpital Cochin, 75014 Paris, France, ${ }^{5}$ Biologie Hormonale et Métabolique, Hôpital Cochin, 75014 Paris, France and ${ }^{6}$ Service de Neurochirurgie, Hôpital FOCH, 92151 Suresnes, France

(Correspondence should be addressed to J Bertherat at Centre de Référence des Maladies Rares de la Surrénale, Service des Maladies Endocriniennes et Métaboliques, Hôpital Cochin; Email: jerome.bertherat@cch.aphp.fr)

\begin{abstract}
Objective: To describe the sequence of hormonal changes during recurrence of Cushing's disease (CD) after successful transsphenoidal surgery (TSS).

Design: Retrospective study in a single center.

Patients and methods: We studied 101 of the 127 patients treated by TSS for CD between 1996 and 2009, who had hypocortisolism or eucortisolism for at least 3 months post-TSS. We arbitrarily defined 'overt recurrence', as presence of two classical parameters of excess cortisol (increased midnight - either serum or salivary - and $24 \mathrm{~h}$ urinary cortisol (UC)), leading to further specific therapeutic action, and 'mild recurrence', as presence of a single classical parameter, leading to simple surveillance.

Results: Of the 101 patients, 21 (20.8\%) presented with recurrence, 'mild' or 'overt', during long-term follow-up (median 50.4 months, range 7-99). Recurrence occurred less frequently (16.8 vs $50 \%$, $P=0.02$ ), and later (mean 44.7 months, median 43, range 7-94 vs mean 21.5 months, median 17 , range $3-61, P=0.05)$, in patients with early post-TSS hypocortisolism compared with those with eucortisolism. Increase in midnight cortisol occurred in a mean time of 38.2 months, while UC elevation was observed at 50.6 months. Vasopressin analogs and CRH tests were eventually positive in 85 and $93 \%$ of all patients respectively; a positive response to one of the two dynamic tests preceded the increase in midnight cortisol or UC in 71 and $64 \%$ of the patients respectively.

Conclusion: A positive response to vasopressin analogs and/or CRH tests occurs early in recurrence, followed by an increase in midnight cortisol, while UC elevation is at a later stage.
\end{abstract}

European Journal of Endocrinology 165 729-737

\section{Introduction}

Cushing's disease $(\mathrm{CD})$ is caused due to excessive production of ACTH from the pituitary gland, leading to chronic hypercortisolism. If left untreated, it leads to increased morbidity and mortality, mainly due to cardiovascular disease (1-4). Early treatment might be important to reduce the long-term consequences of hypercortisolism. Indeed, after curing CD, improvement of cardiovascular risk and psychological manifestations is only partial $(5,6)$.

Transsphenoidal surgery (TSS) is the first-line treatment for $\mathrm{CD}(7,8)$, with long-term cure rates varying from 44 to $90 \%$ (9-20) depending on a surgeon's experience and skill, size and localization of the adenoma, duration of follow-up, and criteria used to define remission and failure. Despite immediate remission, CD recurs with different reported rates primarily dependent on the duration of follow-up. Published short-term recurrence rates vary from 0 to $13 \%$, with a median follow-up of $<2$ years (21-23). Studies with longer follow-up have reported overall recurrence rates of $5-27 \%$, with median times to recurrence of 34-84 months (9-11, 16, 20, 24-29).

Early treatment of $\mathrm{CD}$ recurrence might be important to limit long-term morbidity. This would require predictive factors on the one hand and sensitive biological markers for the diagnosis of recurrence on the other hand. However, parameters that may predict late recurrence after an immediately successful surgery are still debatable. Many studies have suggested that a low early post-TSS morning serum cortisol is a good predictor of cure $(12,13,20,30-32)$. However, up to $31 \%$ of patients with early post-TSS, corticotroph 
deficiency will eventually recur $(10,12,16,33)$. Conversely, an unsuppressed early morning post-TSS serum cortisol level can be associated with long-term remission. Dynamic tests, such as $\mathrm{CRH}$ and vasopressin analogs (lysine vasopressin (LVP) and desmopressin) stimulation tests, and the recently coupled dexamethasone desmopressin test, have been used to predict recurrence $(15,28,29,34-36)$. In patients showing ACTH and cortisol response to desmopressin in the preoperative period, the persistence or the reappearance of the positive response during long-term follow-up could be an early predictor of late recurrence, preceding by several months the classical markers of recurrence and the overt clinical signs of hypercortisolism $(37,38)$. Concerning the hormonal investigations to diagnose recurrence during follow-up, the timing and sequence of these alterations have rarely been investigated. One might expect a period of mild alterations preceding overt hypercortisolism during the recurrence of CD after TSS. It is generally accepted that biological investigations for the diagnosis of mild hypercortisolism are difficult to interpret (39). However, in patients followed up after surgery for $\mathrm{CD}$, the situation might be different because the probability of hypercortisolism recurrence is much higher than the probability of hypercortisolism in the general population.

The aim of this study was to describe the sequence of hormonal changes in patients with recurrent hypercortisolism after successful TSS.

\section{Patients and methods}

\section{Patient population}

We retrospectively analyzed the records of 161 patients with CD who were followed at the Endocrinology Department of Cochin Hospital (Paris, France), diagnosed between January 1996 and December 2009, and who underwent TSS as a first-line treatment. After the exclusion of 34 patients who had a follow-up of $<3$ months, or who were referred to our department with documented failure or recurrence following their first TSS, 127 patients were available for the present analysis. The study was carried out according to the French rules for clinical records analysis in a clinical research setting and with the approval of the National Committee Commission: Nationale de l'informatique et des libertés (CNIL) for clinical computed database management.

\section{Diagnosis of CD}

In the 127 included patients, CD was diagnosed on the basis of an ACTH-dependent Cushing's syndrome associating clinical findings and classical parameters as per guidelines $(40,41)$ including $24-\mathrm{h}$ urinary cortisol (UC) excretion $>90 \mu \mathrm{g} / 24 \mathrm{~h}$, unsuppressed ACTH, absence of circadian rhythm (awake midnight serum cortisol $>75 \mathrm{ng} / \mathrm{ml}$ and/or midnight salivary cortisol $>2 \mathrm{ng} / \mathrm{ml}$ ), no suppression of cortisol after low dose of dexamethasone (UC $>10 \mu \mathrm{g} / 24 \mathrm{~h}$ after $2 \mathrm{mg} /$ day for 2 days and/or serum cortisol $>18 \mathrm{ng} / \mathrm{ml}$ after $1 \mathrm{mg}$ dexamethasone given at $0000 \mathrm{~h}$ ). In addition, the diagnosis was based on histological confirmation of basophilic adenoma with positive immunostaining with anti-ACTH antibody $(n=96)$ or post-surgical hypocortisolism despite negative or inconclusive histology $(n=8)$, or histologic confirmation during a second surgery $(n=4)$, or a central/peripheral ACTH ratio in bilateral inferior petrosal sinus sampling $>2$ (baseline) and/or $>3$ after CRH stimulation $(n=15)$, or a concordant positive response to two dynamic tests (high-dose $(8 \mathrm{mg})$ dexamethasone suppression test, either $\mathrm{CRH}$ or vasopressin analog stimulation test), and no evidence of ectopic ACTH secretion $(n=4)$.

\section{Immediate TSS outcome}

Immediate TSS outcome was assessed by early morning serum cortisol concentration within 2 weeks after TSS, except in six patients who were followed in other medical centers but were referred to our institution as they were still in remission by our criteria. Hypocortisolism was defined by morning serum cortisol $<50 \mathrm{ng} / \mathrm{ml}$ and/or subnormal response to corticotropin analog or to the overnight metyrapone test. Eucortisolism was defined by the absence of hypocortisolism along with the combination of normal UC $(<90 \mu \mathrm{g} / 24 \mathrm{~h})$ and a maintained nycthemeral cortisol cycle (midnight serum cortisol $<75 \mathrm{ng} / \mathrm{ml}$, midnight salivary cortisol $<2 \mathrm{ng} / \mathrm{ml}$ ) (42). Early remission should be maintained for at least 3 months post-TSS, otherwise it would be considered as immediate surgical failure. Twenty-six of the 127 patients $(20.5 \%)$ failed to fulfill these criteria post-TSS, with at least one of the previously mentioned parameters (midnight cortisol or UC) remaining abnormal, and consequently were considered as immediate surgical failures.

\section{Long-term follow-up}

Recurrence was defined as reappearance of hypercortisolism after at least 3 months of hypocortisolism or eucortisolism post-TSS. Based on the hormonal and clinical evaluation, as well as the need for specific therapeutic decision to control the recurrent hypercortisolism, we subdivided the recurrence group into overt and mild recurrence.

Overt recurrence When two classical parameters of excess cortisol were simultaneously present, increased midnight cortisol - either serum $(>75 \mathrm{ng} / \mathrm{ml})$ or salivary $(>2 \mathrm{ng} / \mathrm{ml})$ - and $24 \mathrm{~h} \mathrm{UC}(>90 \mu \mathrm{g} / 24 \mathrm{~h})$, together with related clinical features, lead to further specific therapeutic action. 
Table 1 Comparison of the main characteristics of the patients in maintained remission and the patients with recurrence during follow-up. Values in parentheses are ranges or percentages.

\begin{tabular}{llll}
\hline & $\begin{array}{l}\text { Maintained } \\
\text { remission } \\
(n=80)\end{array}$ & $\begin{array}{l}\text { Recurrence } \\
(n=21)\end{array}$ & $\boldsymbol{P}$ \\
\hline $\begin{array}{l}\text { Mean age at } \\
\quad \text { diagnosis (years) }\end{array}$ & $38.4(15-76)$ & $33.2(17-54)$ & 0.18 \\
$\begin{array}{l}\text { Sex ratio (F/M) } \\
\text { Negative histology }\end{array}$ & $66 / 14$ & $19 / 2$ & 0.51 \\
$\begin{array}{c}\text { Adenoma (m/M) } \\
\text { Mean follow-up }\end{array}$ & $52 / 17$ & $3(14.3 \%)$ & 1 \\
$\quad$ months & $48.8(3.7-148.7)$ & $11 / 7$ & 0.25 \\
$\begin{array}{c}\text { Early post-TSS } \\
\text { hypocortisolism }\end{array}$ & $74(92.5 \%)$ & $15(71.4 \%)$ & 0.02 \\
\hline
\end{tabular}

Mild recurrence This was when a single classical parameter of cortisol excess (see above) was present, with no or minimal clinical manifestations, and, thus, allowing a simple surveillance. Accordingly, the time elapsed from TSS to mild recurrence is the time at which the perturbation of the first classical parameter (midnight cortisol or UC) occurred.

\section{Testing procedures}

Saliva was collected through Plain Salivette kit (Sarstedt, Newton, NC, USA) by placing a cotton wool plug in the mouth for $1-3$ min $(42,43)$. LVP was injected at a dose of $10 \mathrm{U}$ i.m., and desmopressin was injected at a dose of $10 \mu \mathrm{g}$ i.v. as a bolus at time $0 \mathrm{~min}$, and blood samples for plasma ACTH and serum cortisol determinations were collected at $-30,0,15,30,45$, and $60 \mathrm{~min}$. One patient had LVP stimulation test exclusively, and two patients had LVP prior to the desmopressin stimulation test.

Human $\mathrm{CRH}$ was administered at the dose of $100 \mu \mathrm{g}$ i.v. as a bolus at time $0 \mathrm{~min}$, with blood samples for plasma ACTH and serum cortisol determinations collected at $-30,0,15,30,45$, and $60 \mathrm{~min}$.

In $\mathrm{CRH}$ and vasopressin analog stimulation tests, $\triangle \mathrm{ACTH}$ was calculated by the following formula: $\triangle \mathrm{ACTH}=$ (peak ACTH level after stimulation-basal ACTH level before stimulation) and expressed in $\mathrm{pg} / \mathrm{ml}$. The percentage of ACTH increment after stimulation was calculated as follows: \% ACTH increment $=(($ peak ACTH level after stimulation - basal ACTH level before stimulation)/basal ACTH level before stimulation) $X$ 100. When net increments $(\Delta)$ in ACTH were $<22 \mathrm{pg} / \mathrm{ml}$, the hormonal response was considered insufficient, irrespective of the percentage increase.

\section{Hormone assays}

ACTH was assayed using the IRMA ELISA-ACTH (Cis Bio International, Gif sur Yvette, France) (44). Salivary cortisol was assayed with CORT-CT2 RIA (Cis Bio International), as described previously (42).
Serum and UCs were assayed with CORT-CT2 RIA (Cis Bio International) until 2001 and then using the competitive chemiluminescent enzyme immunoassay Immulite 2000 Cortisol (Siemens Healthcare Diagnostics, Erlangen, Germany). UC excretion was expressed as micrograms excreted in urine over a $24 \mathrm{~h}$ period. To convert UC $(\mu \mathrm{g} / 24 \mathrm{~h})$ to System International (SI) units (nmol/24 h), multiply by 2.76 . To convert serum or salivary cortisol $(\mathrm{ng} / \mathrm{ml})$ to SI units $(\mathrm{nmol} / \mathrm{l})$, multiply by 2.76 . To convert plasma ACTH $(\mathrm{pg} / \mathrm{ml})$ to SI units (pmol/l), multiply by 0.22 .

\section{Statistical analysis}

Data are presented as mean, median, and range for descriptive statistics. Groups were compared using the Wilcoxon test or the Fisher test as appropriate. Spearman's correlation coefficient was fitted to indicate correlation between early morning serum cortisol and time elapsed from TSS to first parameter perturbation. All statistical tests were considered significant when $P<0.05$.

\section{Results}

\section{Main patients' characteristics and immediate outcome after TSS}

Of the 127 patients, 101 (79.5\%) were in remission in early post-TSS. The absence of histological confirmation of a corticotroph adenoma was more frequent in cases of failure: 14 of 101 patients with early remission had negative histology compared with 17 of 26 patients in the immediate failure group ( 14 vs $65 \%, P=0.0001$ ).

\section{Characteristics of the maintained remission and recurrence groups}

As shown in Table 1, the mean age at CD diagnosis of the patients in the recurrence group was 33.2 years (17-54) and 19/21 (90\%) patients were women.

Table 2 Comparison of the main characteristics of the patients presenting with early post-transsphenoidal surgery (TSS) hypocortisolism or eucortisolism. Values in parenthese are ranges or percentages.

\begin{tabular}{|c|c|c|c|}
\hline & $\begin{array}{l}\text { Early post-TSS } \\
\text { hypocortisolism } \\
(n=89)\end{array}$ & $\begin{array}{l}\text { Early post-TSS } \\
\text { eucortisolism } \\
(n=12)\end{array}$ & $\boldsymbol{P}$ \\
\hline $\begin{array}{l}\text { Mean age at } \\
\text { diagnosis (years) }\end{array}$ & $37.11(15-76)$ & $38.91(23-59)$ & 0.47 \\
\hline Sex ratio $(F / M)$ & $75 / 14$ & $10 / 2$ & 1 \\
\hline Negative histology & $12(13.4 \%)$ & $2(16.6 \%)$ & 0.67 \\
\hline Adenoma $(\mathrm{m} / \mathrm{M})$ & $57 / 20$ & $6 / 4$ & 0.45 \\
\hline $\begin{array}{l}\text { Mean follow-up } \\
\text { months (median) }\end{array}$ & $49.6(44 ; 3.7-139.9)$ & $45.4(24 ; 3-148.7)$ & 0.33 \\
\hline Recurrence & $15(16.8 \%)$ & $6(50 \%)$ & 0.02 \\
\hline
\end{tabular}


Histological confirmation of a basophilic adenoma was obtained for 18 patients: 11 (61\%) microadenoma, seven (39\%) macroadenoma. Three patients had negative histology. In two cases, a preoperative evaluation by bilateral inferior petrosal sinus sampling showed a central to peripheral gradient $\geq 45$. The third patient had a preoperative aspiration of a $2 \mathrm{~mm}$ microadenoma that was not found on histology but the patient subsequently developed after surgical hypocortisolism (early morning serum cortisol at $10 \mathrm{ng} / \mathrm{ml})$. There was no statistically significant difference between maintained remission and recurrence groups concerning the mean length of follow-up, mean age at diagnosis, sex distribution, histological findings after TSS, or adenoma size. Only the immediate post-TSS outcome had a significant impact on the longterm outcome, as early post-TSS hypocortisolism was a good predictor of maintained remission: $71.4 \%$ of the recurrence group were hypocortisolic post-TSS and $28.6 \%$ were eucortisolic, whereas $92.5 \%$ of the maintained remission group were hypocortisolic postTSS and $7.5 \%$ were eucortisolic $(P=0.02)$. As shown in Table 2, only 15 of the 89 patients $(16.8 \%)$ presenting early post-TSS hypocortisolism demonstrated recurrence, with a mean length of follow-up of 49.6 months (median 44 months, range 3.7-139.9). Conversely, six of the 12 patients $(50 \%)$ with early post-TSS eucortisolism presented recurrence after a mean follow-up period of 45.4 months (median 24, range 3-148.7).
The difference in the recurrence rate was highly significant $(P=0.02)$.

Of the 101 patients, $21(20.8 \%)$ presented with a recurrence during long-term follow-up. Among them, $14(13.8 \%)$ patients ultimately presented with overt recurrence in a mean period of 50.8 months (median 50, range 9-94) from TSS and seven (6.9\%) patients presented with only mild recurrence at their last follow-up after a mean time of 49.6 months from TSS (median 39, range 7-99). Individual characteristics of the 21 patients with recurrence are presented in Table 3.

In the 14 patients who were eventually specifically treated for their recurrent hypercortisolism (see Table 3), time from TSS to 'overt' recurrence was significantly longer in patients who were hypocortisolic post-TSS compared with those who were eucortisolic: mean 62.9 months, median 58.5, range $42-94$ vs mean 17 months, median 19.5, range $3-26(P=0.002$; Fig. 1$)$.

In addition, in the six patients who had post-TSS early morning serum cortisol below $10 \mathrm{ng} / \mathrm{ml}$, the mean time to first classical parameter alteration was longer (60.66 months, median 50.5, range 43-94) than that in the patients with early morning serum cortisol $>10 \mathrm{ng} / \mathrm{ml}$ (27.41 months, median 21.5, range $3-66), P=0.01$. There was a negative correlation between post-TSS early morning serum cortisol, and the time from TSS to first classical parameter alteration ( $r=-0.52 ; P=0.03)$, among the 21 patients with recurrence.

Table 3 Characteristics of the 21 patients presenting recurrence during follow-up.

\begin{tabular}{|c|c|c|c|c|c|c|c|}
\hline \multirow[b]{2}{*}{$\begin{array}{l}\text { Patient } \\
\text { no. }\end{array}$} & \multirow[b]{2}{*}{ Sex } & \multirow[b]{2}{*}{$\begin{array}{c}\text { Age at } \\
\text { diagnosis }\end{array}$} & \multirow[b]{2}{*}{ Histology } & \multirow[b]{2}{*}{$\begin{array}{l}\text { Immediate } \\
\text { TSS outcome }\end{array}$} & \multicolumn{2}{|c|}{$\begin{array}{l}\text { Time from } \\
\text { TSS to altered (months) }\end{array}$} & \multirow[b]{2}{*}{$\begin{array}{l}\text { Therapeutic } \\
\text { action }\end{array}$} \\
\hline & & & & & $\begin{array}{l}\text { Midnight } \\
\text { cortisol }\end{array}$ & 24 h UC & \\
\hline 1 & $\mathrm{~F}$ & 27 & MIA & Eucortisolic & 3 & 9 & $\mathrm{KC}+\mathrm{TSS}$ \\
\hline 2 & $\mathrm{~F}$ & 54 & - ve & Eucortisolic & 26 & 26 & ADRX \\
\hline 3 & $\mathrm{~F}$ & 45 & MAA & Hypocortisolic & 42 & 50 & TSS \\
\hline 4 & $\mathrm{~F}$ & 25 & MAA & Hypocortisolic & 51 & 51 & TSS \\
\hline 5 & $\mathrm{~F}$ & 25 & MAA & Hypocortisolic & 13 & 70 & $\mathrm{TSS}+\mathrm{KC}+\gamma \mathrm{knife}$ \\
\hline 6 & $\mathrm{~F}$ & 21 & $\mathrm{MIA}$ & Hypocortisolic & 44 & 44 & ADRX \\
\hline 7 & $\mathrm{~F}$ & 39 & MAA & Hypocortisolic & 43 & 43 & TSS \\
\hline 8 & $\mathrm{~F}$ & 37 & $\mathrm{MIA}$ & Eucortisolic & 22 & 22 & RT \\
\hline 9 & $\mathrm{~F}$ & 38 & MIA & Hypocortisolic & 66 & 66 & KC $+\gamma$ knife \\
\hline 10 & $\mathrm{~F}$ & 39 & MIA & Hypocortisolic & 94 & 94 & TSS \\
\hline 11 & $\mathrm{~F}$ & 32 & - ve & Hypocortisolic & 78 & 78 & $\mathrm{KC}+\mathrm{ADRX}$ \\
\hline 12 & $\mathrm{~F}$ & 40 & MIA & Hypocortisolic & 36 & 91 & ADRX \\
\hline 13 & $\mathrm{~F}$ & 17 & MIA & Hypocortisolic & 50 & 50 & $\mathrm{Op}^{\prime}+\mathrm{TSS}+\mathrm{ADRX}$ \\
\hline 14 & $\mathrm{~F}$ & 38 & MIA & Eucortisolic & 17 & 14 & $O p^{\prime}+K C+A D R X$ \\
\hline 15 & M & 36 & MIA & Hypocortisolic & 7 & & Observation \\
\hline 16 & $\mathrm{~F}$ & 32 & - ve & Hypocortisolic & 39 & & Observation \\
\hline 17 & $\mathrm{~F}$ & 27 & MAA & Hypocortisolic & 17 & & Observation \\
\hline 18 & $\mathrm{M}$ & 17 & MIA & Hypocortisolic & 48 & & Observation \\
\hline 19 & $\mathrm{~F}$ & 33 & MAA & Hypocortisolic & 43 & & Observation \\
\hline 20 & $\mathrm{~F}$ & 45 & $\mathrm{MIA}$ & Eucortisolic & 61 & & Observation \\
\hline 21 & $\mathrm{~F}$ & 30 & MAA & Eucortisolic & 3 & & Observation \\
\hline
\end{tabular}

Sex: F, female; M, male. Histology: MIA, microadenoma; MAA, macroadenoma; KC, ketoconazole; -ve, negative; Op' ${ }^{\prime}$ mitotane; TSS, transsphenoidal surgery; ADRX, bilateral adrenalectomy; RT, radiotherapy. 


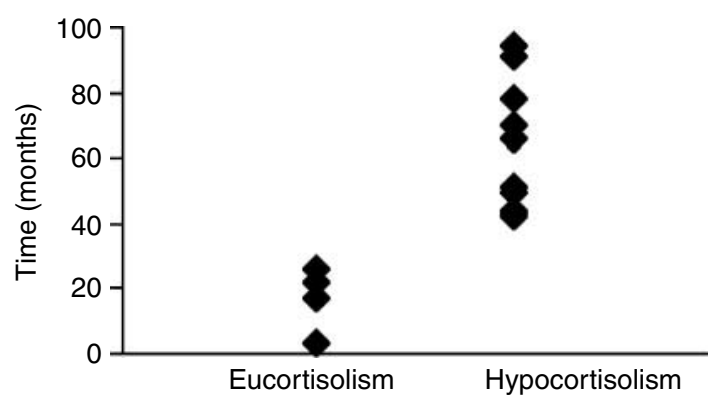

Figure 1 Delay of 'overt' recurrence after transsphenoidal surgery (TSS) according to immediate post-TSS outcome. The figure shows time in months elapsed from TSS to 'overt recurrence' according to immediate post-TSS outcome (hypocortisolism vs eucortisolism).

\section{Description of classical parameters of cortisol excess in recurrence}

The mean time from TSS to the first classical parameter alteration (midnight serum/salivary cortisol or UC) was 38.2 months (median 42, range 3-94).

Midnight cortisol All patients, with either mild or overt recurrence, had an increased midnight cortisol, either serum or salivary, after a mean time of 38.2 months from TSS (median 42, range 3-94). No significant difference was noted between salivary and midnight serum cortisol, in terms of time from TSS to individual disturbance of each $(P=0.977)$.

In early post-TSS eucortisolic patients, the mean time from TSS to increased midnight cortisol was 22 months (median 19.5, range 3-61) compared with 44.7 months (median 43, range 7-94) in early post-TSS hypocortisolic patients $(P=0.05)$. In the seven patients with mild recurrence only (see Table 3, patients 15-21), increased midnight cortisol occurred in a mean time of 31.1 months from TSS (median 39, range 3-61).

$24 \mathrm{~h}$ UC Eleven of the 21 (52.3\%) patients with recurrence had increased midnight cortisol while UC became elevated later (patients 1, 3, 5, and 12, Table 3) or was still within normal limits at their last follow-up (patients 15-21, Table 3); in nine patients $(42.8 \%)$, both parameters were altered simultaneously (patients $2,4,6-11$, and 13 , Table 3 ). In only one case, UC was the first classical parameter to become abnormal, preceded by 3-month increased midnight cortisol (patient 14, Table 3).

Figure 2 shows the mean of the UC of the two groups of patients with 'overt' or 'mild' recurrence, prior to TSS, in the immediate post-TSS period and at the time of the recurrence diagnosis: the overt and mild recurrence groups had similar values preoperatively (436.2 vs $260.1 \mu \mathrm{g} / 24 \mathrm{~h}, P=0.18$ ); early post-TSS UC values were all normal but the 'overt' group had slightly, non-significant, higher mean (14.5 vs $13.9 \mu \mathrm{g} / 24 \mathrm{~h}$, $P=0.78)$; at the time of recurrence, a significant difference was observed $(290.5$ vs $70.4 \mu \mathrm{g} / 24 \mathrm{~h}$, $P=0.0004$ ), with all 'overt' patients having high UC and all 'mild' patients having normal UC values.

\section{Results of vasopressin analog and CRH tests in recurrence}

Seventeen of the $20(85 \%)$ patients who had a vasopressin analog stimulation test (LVP in three patients and desmopressin in 17 patients) during their follow-up ultimately had a positive response. In six patients, the ACTH response was lost post-operatively, only to reappear later during follow-up. Three of the 20 patients remained non-responders during the long-term follow-up: one was a non-responder before TSS and the two other patients had a positive test before surgery.

In the 17 responder patients, a positive response to vasopressin analogs preceded the first classical parameter alteration in $12(71 \%)$ cases. In two patients, test positivity was documented after increased midnight cortisol and in three patients was concomitant to increased midnight cortisol and/or increased UC. Overall, vasopressin analog test positivity after TSS was observed before the first classical parameter alteration (24.4 months, median 7, range 0-94, vs 39.9 months, median 43 , range $3-94, P=0.049$ ).

Time from TSS to vasopressin analog test positivity was significantly shorter in immediate post-TSS eucortisolic than hypocortisolic patients: 3.2 months (median 3, range 0-7) vs 33.2 months (median 26, range 0-94), $P=0.02$. A positive response was observed in six patients that were still hypocortisolic.

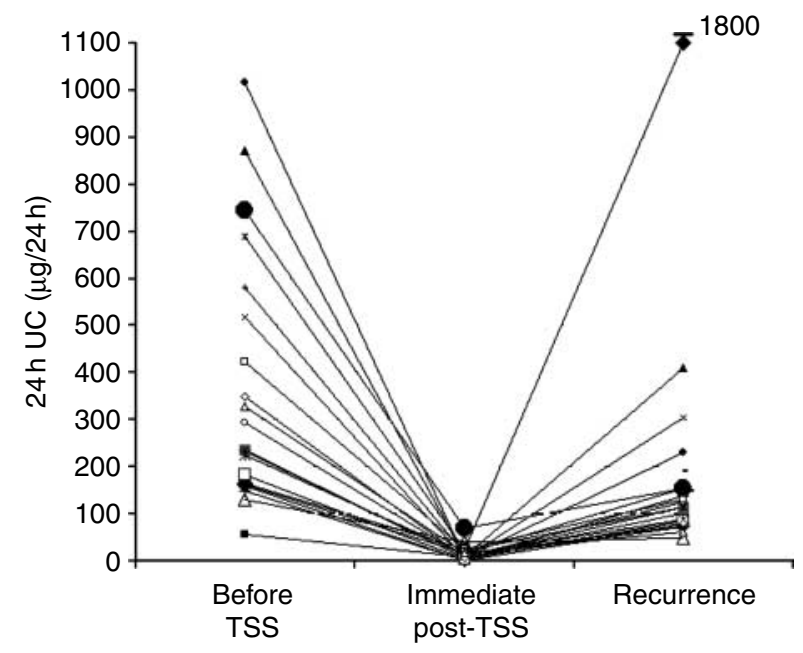

Figure 2 Urinary cortisol (UC) evolution before surgery and during follow-up in recurring patients. The figure shows the evolution of $\mathrm{UC}(\mu \mathrm{g} / 24 \mathrm{~h})$ in the 21 recurring patients. This includes, for each patient, the UC before transsphenoidal surgery (TSS) (before TSS), the immediate post-TSS UC (immediate post-TSS), and the highest UC value observed during recurrence for patients with overt recurrence, or at last follow-up for patients with mild recurrence (recurrence). 


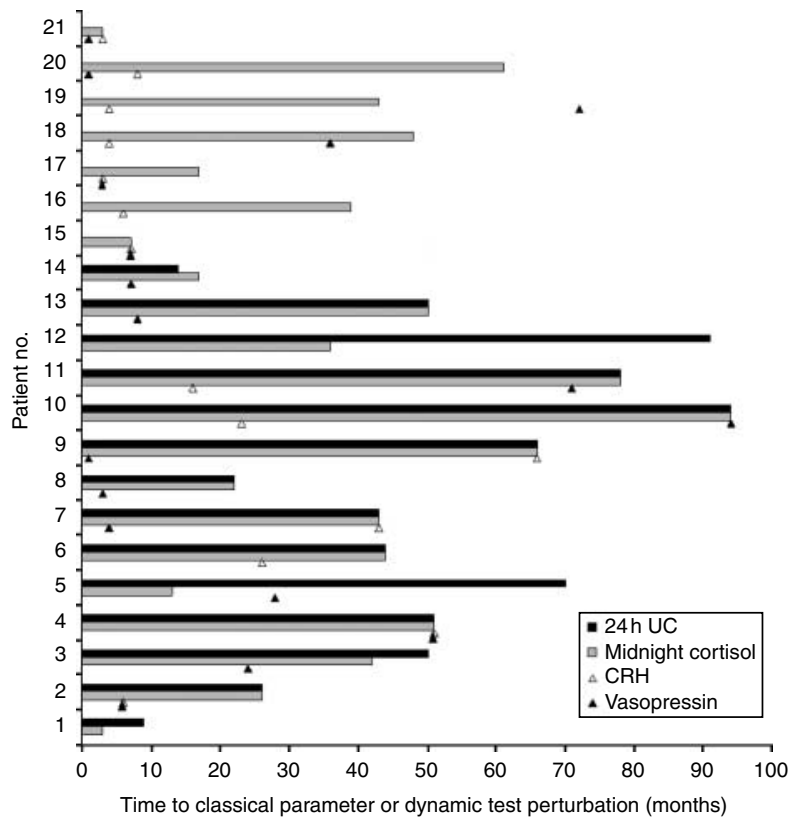

Figure 3 Delay in the alterations of hormonal investigations in patients with recurrence. The figure shows for each of the 21 recurrence patients the time in months elapsed from transsphenoidal surgery (TSS) to vasopressin analog and CRH tests positivity and to cycle and urinary cortisol (UC) perturbation. An absent mark reflects that the test was not done, except for vasopressin analog tests in patients 1,6 , and 16 and $\mathrm{CRH}$ test in patient 1 , in whom tests were done but were negative. Patients 15-21 are in the mild recurrence group and therefore still have normal UC.

Fifteen of the 21 patients had a CRH stimulation test during their follow-up. Fourteen of them $(93 \%)$ ultimately had a positive response. The mean time from TSS to test positivity was 19 months (median 7.5, range 3-66). In CRH stimulation responders, test positivity preceded the first classical parameter alteration in nine of 14 cases $(64 \%)$. In the remaining five patients, CRH positivity was documented concomitant to first classical parameter alteration. In three patients, there was no correlation between pre- and postoperative response to $\mathrm{CRH}$ stimulation. In $\mathrm{CRH}$ responders, the mean time from TSS to first classical parameter alteration was 44.3 months (median 43.5, range 3-94) and was significantly longer than the time to $\mathrm{CRH}$ test positivity $(P=0.014)$.

Figure 3 shows for each patient the time from TSS to documented response to stimulation tests (vasopressin analog or $\mathrm{CRH}$ ), to midnight cortisol and/or UC increase. UC appears to be the latest biochemical parameter of recurrence, preceded by the midnight cortisol and the response to the stimulation tests.

\section{Discussion}

In this study, immediate and long-term post-TSS remission rates, 79.5 and $63 \%$ respectively, are similar to those in previous large study (varying between 59 and $100 \%$ for immediate remission and between 44 and $90 \%$ for maintained remission) $(9-20,26)$. Patients with negative histology had more frequent early surgical failure but, when in remission, did not recur more frequently. This was also observed in other studies $(19,26)$. The adenoma size also did not impact on the recurrence rate, when comparing microadenomas and macroadenomas.

Recurrence is more frequent in patients with higher serum cortisol values in the immediate post-operative period $(15-17,21)$. Undetectable early morning serum cortisol $(<18 \mathrm{ng} / \mathrm{ml}, 50 \mathrm{nmol} / \mathrm{l})$ is as a good index of long-term remission $(10,16,17,20,29-32,42)$. Yet, it is not a full protector $(10-12,16,20,21,29,33$, $42,45)$. We show here that immediate post-TSS hypocortisolism was associated with better long-term outcome: $92.5 \%$ of patients who did not recur were hypocortisolic post-TSS. Yet, 50\% of our patients with late recurrence had early morning plasma cortisol below $18 \mathrm{ng} / \mathrm{ml}$ and $33.3 \%$ had levels below $10 \mathrm{ng} / \mathrm{ml}$. Interestingly, we show, for the first time, that recurrence occurred earlier in patients with early post-TSS eucortisolism compared to hypocortisolic patients. This was especially noted when taking into consideration the time elapsed to overt recurrence and UC elevation. In the hypocortisolic group, the perturbation of the first classical parameter of hypercortisolism can occur early as well as late during follow-up, but in the eucortisolic group, all patients but one had altered cortisol parameters within the first 2 years post-TSS.

In patients with overt recurrence, cycle disturbances were either documented simultaneously or preceded UC elevation, except in one patient who had post-TSS eucortisolism and in whom the UC elevation was documented 3 months earlier than cycle disturbance. All patients with mild recurrence exhibit cortisol cycle disturbances, and despite the gradual increase in their UC excretion (data not shown), the latter is still normal 18 months after the increase in midnight cortisol. We believe that mild recurrence is nothing but an early phase of recurrence and that all seven patients in the mild recurrence group will eventually show overt recurrence and thus need close follow-up. Whether specific treatment might already be started in such cases should be discussed.

Several studies suggest that the post-operative response to desmopressin stimulation test may predict long-term recurrence after TSS. Some reported the absence of recurrence in patients who had disappearance of the response to desmopressin (37), while others found that the persistence of a response in the early post-operative period might help to identify patients at risk for late recurrence $(28,45)$. We did not directly assess the predictive value of persistent ACTH response to desmopressin post-operatively, but our description of the recurrence patients shows that loss of response to desmopressin stimulation early post-operatively does 
not always predict a maintained remission and that a positive response might reappear during long-term follow-up. There is no consensus on the response criteria to $\mathrm{CRH}$ and desmopressin stimulation tests. Our criteria of positivity were based on ACTH response in previous reports $(37,45)$. The desmopressin test positivity was observed in $85 \%$ of recurring patients, and preceded the increased midnight cortisol or UC in $71 \%$ of them, and even preceded the resolution of the hypocortisolic state in $40 \%$ of them.

ACTH responsiveness to an early post-operative $\mathrm{CRH}$ has also been suggested as a valuable index to identify patients at risk of recurrence $(15,36)$. One previous study found no relapses in patients who did not respond to CRH (26). In our study, a positive response to $\mathrm{CRH}$ stimulation test was ultimately documented in $93 \%$ of recurring patients who had the test performed in a mean of 19 months (range 3-66) post-TSS. Response to $\mathrm{CRH}$ preceded the increased midnight cortisol or UC in $64 \%$ of the patients. Our data does not allow a comparative evaluation of $\mathrm{CRH}$ and desmopressin stimulation tests.

There are some limitations to our study, mainly related to its retrospective nature. In addition, in a tertiary center, we receive patients with various followup from other medical centers after remission. This could explain the concomitant perturbation of tests in those patients, while in patients followed more closely, the delay between stimulation test positivity and cycle or UC perturbation is longer. Another point is the lack of data concerning $\mathrm{CRH}$ and vasopressin analog stimulation tests in the group who had maintained remission. Particularly considering the fact that a positive $\mathrm{CRH}$ response may also be associated with the mere normalization of the corticotroph axis. However, our study was not designed to assess criteria for recurrence prediction but rather to describe the sequence of some hormonal events during recurrence.

In conclusion, prediction of late recurrence of hypercortisolism after successful TSS for CD is difficult. Post-surgical hypocortisolism predicts a better outcome and a longer remission period. However, undetectable post-TSS early morning serum cortisol does not exclude recurrence, nor does post-TSS eucortisolism imply definite relapse. Disappearance of ACTH response to desmopressin early post-TSS does not guarantee complete adenoma resection, and this response could reappear during long-term follow-up. This difficulty underlines the importance of long-term follow-up to identify recurrences of CD that may occur years after successful TSS. This study shows that $\mathrm{CRH}$ and desmopressin test positivity usually precede alterations of midnight cortisol or UC, considered as the classical biological parameters for Cushing's syndrome diagnosis. Furthermore, UC increase is late during recurrence. This questions the need for new tools or criteria for CD follow-up after TSS to diagnose it at an early stage, when hypercortisolism is mild, allowing to reduce its clinical consequences. This study suggests that dynamic $\mathrm{CRH}$ or vasopressin tests, as well as midnight cortisol, might be more sensitive than UC to detect patients needing closer follow-up or more extensive investigations.

\section{Declaration of interest}

The authors declare that there is no conflict of interest that could be perceived as prejudicing the impartiality of the research reported.

\section{Funding}

The management of the database used for this analysis was supported in part by Novartis.

\section{Acknowledgements}

We thank the staff of the Endocrinology Department of Cochin Hospital and the Neurosurgery Department of Foch Hospital for managing patients and the staff of the Hormonal Biology Department of Cochin Hospital for hormone assays.

\section{References}

1 Dekkers OM, Biermasz NR, Pereira AM, Roelfsema F, van Aken MO, Voormolen JH \& Romijn JA. Mortality in patients treated for Cushing's disease is increased, compared with patients treated for nonfunctioning pituitary macroadenoma. Journal of Clinical Endocrinology and Metabolism 200792 976-981. (doi:10.1210/jc. 2006-2112)

2 Newell-Price J, Bertagna X, Grossman AB \& Nieman LK. Cushing's syndrome. Lancet 2006367 1605-1617. (doi:10.1016/S01406736(06)68699-6)

3 Etxabe J \& Vazquez JA. Morbidity and mortality in Cushing's disease: an epidemiological approach. Clinical Endocrinology 1994 40 479-484. (doi:10.1111/j.1365-2265.1994.tb02486.x)

4 Lindholm J, Juul S, Jorgensen JO, Astrup J, Bjerre P, FeldtRasmussen U, Hagen C, Jorgensen J, Kosteljanetz M, Kristensen L, Laurberg P, Schmidt K \& Weeke J. Incidence and late prognosis of Cushing's syndrome: a population-based study. Journal of Clinical Endocrinology and Metabolism 200186 117-123. (doi:10.1210/jc. 86.1.117)

5 Colao A, Pivonello R, Spiezia S, Faggiano A, Ferone D, Filippella M, Marzullo P, Cerbone G, Siciliani M \& Lombardi G. Persistence of increased cardiovascular risk in patients with Cushing's disease after five years of successful cure. Journal of Clinical Endocrinology and Metabolism $1999 \mathbf{8 4}$ 2664-2672. (doi:10.1210/jc.84.8. 2664)

6 Tiemensma J, Kokshoorn NE, Biermasz NR, Keijser BJ, Wassenaar MJ, Middelkoop HA, Pereira AM \& Romijn JA. Subtle cognitive impairments in patients with long-term cure of Cushing's disease. Journal of Clinical Endocrinology and Metabolism 201095 2699-2714. (doi:10.1210/jc.2009-2032)

7 Arnaldi G, Angeli A, Atkinson AB, Bertagna X, Cavagnini F, Chrousos GP, Fava GA, Findling JW, Gaillard RC, Grossman AB, Kola B, Lacroix A, Mancini T, Mantero F, Newell-Price J, Nieman LK, Sonino N, Vance ML, Giustina A \& Boscaro M. Diagnosis and complications of Cushing's syndrome: a consensus statement. Journal of Clinical Endocrinology and Metabolism 2003 88 5593-5602. (doi:10.1210/jc.2003-030871)

8 Biller BM, Grossman AB, Stewart PM, Melmed S, Bertagna X, Bertherat J, Buchfelder M, Colao A, Hermus AR, Hofland LJ, Klibanski A, Lacroix A, Lindsay JR, Newell-Price J, Nieman LK, Petersenn S, Sonino N, Stalla GK, Swearingen B, Vance ML, Wass JA \& Boscaro M. Treatment of adrenocorticotropin- 
dependent Cushing's syndrome: a consensus statement. Journal of Clinical Endocrinology and Metabolism 200893 2454-2462. (doi:10.1210/jc.2007-2734)

9 Atkinson AB, Kennedy A, Wiggam MI, McCance DR \& Sheridan B. Long-term remission rates after pituitary surgery for Cushing's disease: the need for long-term surveillance. Clinical Endocrinology 200563 549-559. (doi:10.1111/j.1365-2265.2005.02380.x)

10 Patil CG, Prevedello DM, Lad SP, Vance ML, Thorner MO, Katznelson L \& Laws ER Jr. Late recurrences of Cushing's disease after initial successful transsphenoidal surgery. Journal of Clinical Endocrinology and Metabolism 200893 358-362. (doi:10.1210/ jc.2007-2013)

11 Rees DA, Hanna FW, Davies JS, Mills RG, Vafidis J \& Scanlon MF. Long-term follow-up results of transsphenoidal surgery for Cushing's disease in a single centre using strict criteria for remission. Clinical Endocrinology 200256 541-551. (doi:10. 1046/j.1365-2265.2002.01511.x)

12 Yap LB, Turner HE, Adams CB \& Wass JA. Undetectable postoperative cortisol does not always predict long-term remission in Cushing's disease: a single centre audit. Clinical Endocrinology 200256 25-31. (doi:10.1046/j.0300-0664.2001.01444.x)

13 Chee GH, Mathias DB, James RA \& Kendall-Taylor P. Transsphenoidal pituitary surgery in Cushing's disease: can we predict outcome? Clinical Endocrinology 200154 617-626. (doi:10. 1046/j.1365-2265.2001.01261.x)

14 Swearingen B, Biller BM, Barker FG II, Katznelson L, Grinspoon S, Klibanski A \& Zervas NT. Long-term mortality after transsphenoidal surgery for Cushing disease. Annals of Internal Medicine $1999130821-824$.

15 Avgerinos PC, Chrousos GP, Nieman LK, Oldfield EH, Loriaux DL \& Cutler GB Jr. The corticotropin-releasing hormone test in the postoperative evaluation of patients with Cushing's syndrome. Journal of Clinical Endocrinology and Metabolism 1987 65 906-913. (doi:10.1210/jcem-65-5-906)

16 Bochicchio D, Losa M \& Buchfelder M. Factors influencing the immediate and late outcome of Cushing's disease treated by transsphenoidal surgery: a retrospective study by the European Cushing's Disease Survey Group. Journal of Clinical Endocrinology and Metabolism 199580 3114-3120. (doi:10.1210/jc.80.11. 3114)

17 Pieters GF, Hermus AR, Meijer E, Smals AG \& Kloppenborg PW. Predictive factors for initial cure and relapse rate after pituitary surgery for Cushing's disease. Journal of Clinical Endocrinology and Metabolism 198969 1122-1126. (doi:10.1210/jcem-69-6-1122)

18 Guilhaume B, Bertagna X, Thomsen M, Bricaire C, Vila-Porcile E, Olivier L, Racadot J, Derome P, Laudat MH, Girard F, Bricaire H \& Luton JP. Transsphenoidal pituitary surgery for the treatment of Cushing's disease: results in 64 patients and long term follow-up studies. Journal of Clinical Endocrinology and Metabolism $1988 \mathbf{6 6}$ 1056-1064. (doi:10.1210/jcem-66-5-1056)

19 Mampalam TJ, Tyrrell JB \& Wilson CB. Transsphenoidal microsurgery for Cushing disease. A report of 216 cases. Annals of Internal Medicine 1988109 487-493.

20 Pereira AM, van Aken MO, van Dulken H, Schutte PJ, Biermasz NR, Smit JW, Roelfsema F \& Romijn JA. Long-term predictive value of postsurgical cortisol concentrations for cure and risk of recurrence in Cushing's disease. Journal of Clinical Endocrinology and Metabolism $2003 \mathbf{8 8}$ 5858-5864. (doi:10. 1210/jc.2003-030751)

21 Bigos ST, Somma M, Rasio E, Eastman RC, Lanthier A, Johnston HH \& Hardy J. Cushing's disease: management by transsphenoidal pituitary microsurgery. Journal of Clinical Endocrinology and Metabolism 198050 348-354. (doi:10.1210/ jcem-50-2-348)

22 Salassa RM, Laws ER Jr, Carpenter PC \& Northcutt RC. Transsphenoidal removal of pituitary microadenoma in Cushing's disease. Mayo Clinic Proceedings 197853 24-28.

23 Arnott RD, Pestell RG, McKelvie PA, Henderson JK, McNeill PM \& Alford FP. A critical evaluation of transsphenoidal pituitary surgery in the treatment of Cushing's disease: prediction of outcome. Acta Endocrinologica 1990123 423-430.
24 Chen JC, Amar AP, Choi S, Singer P, Couldwell WT \& Weiss MH. Transsphenoidal microsurgical treatment of Cushing disease: postoperative assessment of surgical efficacy by application of an overnight low-dose dexamethasone suppression test. Journal of Neurosurgery 200398 967-973. (doi:10.3171/jns.2003.98.5. 0967)

25 Ram Z, Nieman LK, Cutler GB Jr, Chrousos GP, Doppman JL \& Oldfield EH. Early repeat surgery for persistent Cushing's disease. Journal of Neurosurgery 199480 37-45. (doi:10.3171/jns.1994. 80.1.0037)

26 Invitti C, Pecori Giraldi F, de Martin M \& Cavagnini F. Diagnosis and management of Cushing's syndrome: results of an Italian multicentre study. Study Group of the Italian Society of Endocrinology on the Pathophysiology of the HypothalamicPituitary-Adrenal Axis. Journal of Clinical Endocrinology and Metabolism 199984 440-448. (doi:10.1210/jc.84.2.440)

27 Hammer GD, Tyrrell JB, Lamborn KR, Applebury CB, Hannegan ET, Bell S, Rahl R, Lu A \& Wilson CB. Transsphenoidal microsurgery for Cushing's disease: initial outcome and long-term results. Journal of Clinical Endocrinology and Metabolism 200489 6348-6357. (doi:10.1210/jc.2003-032180)

28 Romanholi DJ, Machado MC, Pereira CC, Danilovic DS, Pereira MA, Cescato VA, Cunha Neto MB, Musolino NR, de Mendonca BB \& Salgado LR. Role for postoperative cortisol response to desmopressin in predicting the risk for recurrent Cushing's disease. Clinical Endocrinology 200869 117-122. (doi:10.1111/j.1365-2265.2007.03168.x)

29 Castinetti F, Martinie M, Morange I, Dufour H, Sturm N, Passagia JG, Conte-Devolx B, Chabre O \& Brue T. A combined dexamethasone desmopressin test as an early marker of postsurgical recurrence in Cushing's disease. Journal of Clinical Endocrinology and Metabolism 200994 1897-1903. (doi:10. $1210 /$ jc.2008-2234)

30 Trainer PJ, Lawrie HS, Verhelst J, Howlett TA, Lowe DG, Grossman AB, Savage MO, Afshar F \& Besser GM. Transsphenoidal resection in Cushing's disease: undetectable serum cortisol as the definition of successful treatment. Clinical Endocrinology $1993 \mathbf{3 8}$ 73-78. (doi:10.1111/j.1365-2265.1993.tb00975.x)

31 Esposito F, Dusick JR, Cohan P, Moftakhar P, McArthur D, Wang C, Swerdloff RS \& Kelly DF. Clinical review: early morning cortisol levels as a predictor of remission after transsphenoidal surgery for Cushing's disease. Journal of Clinical Endocrinology and Metabolism 200691 7-13. (doi:10.1210/jc.2005-1204)

32 Estrada J, Garcia-Uria J, Lamas C, Alfaro J, Lucas T, Diez S, Salto L \& Barcelo B. The complete normalization of the adrenocortical function as the criterion of cure after transsphenoidal surgery for Cushing's disease. Journal of Clinical Endocrinology and Metabolism 200186 5695-5699. (doi:10.1210/jc.86.12.5695)

33 Rollin GA, Ferreira NP, Junges M, Gross JL \& Czepielewski MA. Dynamics of serum cortisol levels after transsphenoidal surgery in a cohort of patients with Cushing's disease. Journal of Clinical Endocrinology and Metabolism 200489 1131-1139. (doi:10. 1210/jc.2003-031170)

34 Losa M, Bianchi R, Barzaghi R, Giovanelli M \& Mortini P. Persistent adrenocorticotropin response to desmopressin in the early postoperative period predicts recurrence of Cushing's disease. Journal of Clinical Endocrinology and Metabolism 200994 3322-3328. (doi:10.1210/jc.2009-0844)

35 Schrell U, Fahlbusch R, Buchfelder M, Riedl S, Stalla GK \& Muller OA. Corticotropin-releasing hormone stimulation test before and after transsphenoidal selective microadenomectomy in 30 patients with Cushing's disease. Journal of Clinical Endocrinology and Metabolism 198764 1150-1159. (doi:10. 1210/jcem-64-6-1150)

36 Colombo P, Dall'Asta C, Barbetta L, Re T, Passini E, Faglia G \& Ambrosi B. Usefulness of the desmopressin test in the postoperative evaluation of patients with Cushing's disease. European Journal of Endocrinology 2000143 227-234. (doi:10.1530/eje.0. 1430227) 
37 Dall'asta C, Barbetta L, Bonavina L, Beck-Peccoz P \& Ambrosi B. Recurrence of Cushing's disease preceded by the reappearance of ACTH and cortisol responses to desmopressin test. Pituitary 2004 7 183-188. (doi:10.1007/s11102-005-0425-9)

38 Ambrosi B, Malavazos AE, Passeri E \& Dall'Asta C. Desmopressin test may predict the risk of recurrence in Cushing's disease. Clinical Endocrinology 2009 70 811. (doi:10.1111/j.1365-2265.2008. 03406.x)

39 Kidambi S, Raff H \& Findling JW. Limitations of nocturnal salivary cortisol and urine free cortisol in the diagnosis of mild Cushing's syndrome. European Journal of Endocrinology 2007157 725-731. (doi:10.1530/EJE-07-0424)

40 Guignat L \& Bertherat J. The diagnosis of Cushing's syndrome: an Endocrine Society Clinical Practice Guideline: commentary from a European perspective. European Journal of Endocrinology 2010163 9-13. (doi:10.1530/EJE-09-0627)

41 Nieman LK, Biller BM, Findling JW, Newell-Price J, Savage MO, Stewart PM \& Montori VM. The diagnosis of Cushing's syndrome: an Endocrine Society Clinical Practice Guideline. Journal of Clinical Endocrinology and Metabolism 200893 1526-1540. (doi:10. 1210/jc.2008-0125)

42 Carrasco CA, Coste J, Guignat L, Groussin L, Dugue MA, Gaillard S, Bertagna X \& Bertherat J. Midnight salivary cortisol determination for assessing the outcome of transsphenoidal surgery in Cushing's disease. Journal of Clinical Endocrinology and Metabolism 200893 4728-4734. (doi:10.1210/jc.2008-1171)

43 Yaneva M, Mosnier-Pudar H, Dugue MA, Grabar S, Fulla Y \& Bertagna X. Midnight salivary cortisol for the initial diagnosis of Cushing's syndrome of various causes. Journal of Clinical Endocrinology and Metabolism 200489 3345-3351. (doi:10. 1210/jc.2003-031790)

44 Assie G, Bahurel H, Coste J, Silvera S, Kujas M, Dugue MA, Karray F, Dousset B, Bertherat J, Legmann P \& Bertagna X. Corticotroph tumor progression after adrenalectomy in Cushing's disease: a reappraisal of Nelson's syndrome. Journal of Clinical Endocrinology and Metabolism 200792 172-179. (doi:10.1210/jc.2006-1328)

45 Valero R, Vallette-Kasic S, Conte-Devolx B, Jaquet P \& Brue T. The desmopressin test as a predictive factor of outcome after pituitary surgery for Cushing's disease. European Journal of Endocrinology 2004151 727-733. (doi:10.1530/eje.0.1510727)

Received 11 May 2011

Revised version received 12 August 2011

Accepted 1 September 2011 